\title{
Immigration and Integration in Urban Communities: Renegotiating the City
}

\author{
Lisa M. Hanley, Blair A. Ruble and Allison M. Garland (Eds.) \\ Baltimore: The John Hopkins University Press, 2008 \\ ISBN: 978-0801888410 \\ $\$ 55.00$ (Hardcover), 336 pages
}

\author{
Eric Fong \\ Department of Sociology \\ University of Toronto \\ Email: fong@ chass.utoronto.ca
}

The integration of immigrants results from the interactive processes between immigrants and their host communities. Therefore, the study of immigrant adaptation should fully incorporate the community effect and acknowledge the uniqueness of the integration pattern in each city. To address this issue, the editors of this book have gathered researchers from diverse disciplines such as anthropology, geography, law, political science, sociology and urban planning. These papers are the products of a series of seminars of the Comparative Urban Studies Project of the Woodrow Wilson International Center for Scholars in 2004 and 2005. Their studies cover a number of cities, such as Dallas-Fort Worth in Texas, Los Angeles in California, Rockland County in New York, Seattle in Washington, and Washington, DC. In addition to these American cities, chapters also include Johannesburg in South Africa, Rome in Italy, Vancouver in Canada, and Stuttgart and Munich in Germany.

The first part of the book focuses on the negotiation of urban space between immigrants and their city. In the first chapter, Michael Jones-Correa examines the racial sorting of different racial and ethnic groups in Washington DC, exploring how ethnic organizations respond in the city and suburbs, and how policies respond to demographic changes. In Chapter 2, Rhacel Salazar Parrenas looks at the experiences of Filipino domestic migrants in Los Angeles and Rome, and shows how they are excluded from the social and physical space of their host societies. The study demonstrates the importance of race and class in understanding women migrants. In Chapter 3, Serin Houston and Richard Wright explore how immigrants interact with space through their daily activities, such as household leisure activities, in mixed households that are headed by partners of different race, one being an immigrant. Chapter 4 is based on discussion of the public space of Muslims in Europe. Chantal Saint-Blancat 
looks at how the local and Muslim populations negotiate the location of mosques. In Chapter 5, Abdou Maliq Simone addresses issues of urbanization and migration by focusing on social and political dynamics in Johannesburg.

The second part of the book consists of five chapters that examine the negotiation of citizenship. Caroline Brettell in Chapter 6 studies the incorporation of immigrants in the city and suburban area of Dallas-Fort Worth. In the discussion, she notes the importance of the cultural dimension in community development. In Chapter 7, David Ley shows how the issue of "monster homes" in Vancouver reflects the political negotiation of an immigrant community and a local government within a policy framework of multiculturalism. In Chapter 8, Jason Pribilsky provides an analysis of public health and immigration. He argues that public health should take into consideration the transnational nature of today's immigrants. In Chapter 9, Barbara Schmitter Heisler explores how Germany, though recognized as not welcoming immigrants, is able to avoid major conflicts between immigrants and local residents through various policies. The study focuses on two German cities, Stuttgart and Munich. In the final chapter, Dickson Eyoh describes how changes in political and economic conditions affect cross border migration and the attitudes of the state toward immigration in Africa.

The book provides a number of case studies that address the interaction between immigrants and their host communities. The diversity of topics covered, ranging from migrant domestic workers to location of mosques, can be seen as a strength of the book. At the same time it is a weakness. Despite the effort made by the editors to tie the topics together, each chapter addresses a set of complicated issues beyond the simple concept of negotiation between immigrant and host community. For example, the chapter by Parrenas on Filipino migrant domestic workers involves issues of race, class, and gender, while Ley's chapter on monster homes in Vancouver is related to national policy and urban planning. Nevertheless, these cases offer us better understanding of a variety of issues related to immigrant adaptation in different cities. 